\title{
Cristina Azuela, Les métaphores érotiques des 'Cent Nouvelles Nouvelles': sexe et écriture
}

\section{Maria Colombo Timelli}

\section{OpenEdition}

1 Journals

Édition électronique

URL : http://journals.openedition.org/studifrancesi/34418

DOI : 10.4000/studifrancesi.34418

ISSN : 2427-5856

Éditeur

Rosenberg \& Sellier

\section{Édition imprimée}

Date de publication : 1 novembre 2005

Pagination : 394

ISSN : 0039-2944

\section{Référence électronique}

Maria Colombo Timelli, « Cristina Azuela, Les métaphores érotiques des 'Cent Nouvelles Nouvelles': sexe et écriture », Studi Francesi [En ligne], 146 (XLIX | II) | 2005, mis en ligne le 30 novembre 2015, consulté le 19 avril 2021. URL : http://journals.openedition.org/studifrancesi/34418 ; DOI : https://doi.org/ 10.4000/studifrancesi.34418

Ce document a été généré automatiquement le 19 avril 2021.

\section{(c) (i) $\odot$}

Studi Francesi è distribuita con Licenza Creative Commons Attribuzione - Non commerciale - Non opere derivate 4.0 Internazionale. 


\title{
Cristina Azuela, Les métaphores érotiques des 'Cent Nouvelles Nouvelles': sexe et écriture
}

\author{
Maria Colombo Timelli
}

\section{RÉFÉRENCE}

CRISTINA AZUELA, Les métaphores érotiques des 'Cent Nouvelles Nouvelles': sexe et écriture, «Fifteenth-Century Studies», 29, 2004, pp. 35-51.

1 Si les nouvelles qui composent le célèbre recueil du $\mathrm{XV}^{\mathrm{e}}$ siècle fonctionnent sur une gamme de situations relativement réduite, en revanche une extraordinaire richesse se déploie sur le plan langagier et stylistique. Parmi les jeux de mots et surprises de langage divers qui caractérisent cette écriture, les métaphores érotiques jouent un rôle fondamental, qui permet tour à tour à l'auteur, au conteur et aux personnages, de voiler la réalité par des procédés de dissimulation ou de parvenir à leur but, d'obtenir quelque chose. Cependant, derrière les nombreuses métaphores qui émaillent les récits se dessine surtout une réflexion consciente au sujet de l'ambivalence du langage et de son arbitraire. 